\title{
Dyspepsia Meckeli
}

\author{
DON ClARK, MD, FRCPC, DILIP G PATEL, MD, FRCPC,
}

ABSTRACT: A 40-year-old male was seen for evaluation of minor gastrointestinal bleeding. The patient had received an $\mathrm{H}_{2}$ blocker as an outpatient for suspicion of duodenal ulcer disease. At endoscopy no lesion was seen and $\mathrm{H}_{2}$ blockers were discontinued. The patient developed acute abdomen and at surgery a perforated Meckel's diverticulum was found. Can J Gastroenterol 1990;4(4):157-159

Key Words: $\mathrm{H}_{2}$ blockers, Meckel's diverticulum

\section{Dyspepsie du diverticule de Meckel}

RESUME: Un patient âgé de 40 ans et souffrant de saignements gastriques légers a été examiné. Soupçonnant un ulcère gastroduodénal, le médecin a prescrit un anti- $\mathrm{H}_{2}$ sans hospitaliser le sujet. L'endoscopie n'ayant décelé aucune lésion, le traitemert par anti- $\mathrm{H}_{2}$ a été interrompu. Le patient a développé un syndrome abdominal aigu et l'intervention chirurgicale a révélé un diverticule de Meckel perforé.
A 40-YEAR-OLD MALE PRESENTED with a one year history of periumbilical crampy discomfort. The pain began 30 to 60 mins after eating and disappeared 2 to $3 \mathrm{~h}$ later. There were noother precipitating or modifying factors and the patient had no other gastrointestinal complaints. He was not on any medications, nor did he smoke ordrink alcohol; he had a positive famiIy history of duodenal ulcer disease. Outpatient investigations included a normal complete blood count and upper gastrointestinal series with small bowel follow through. Small bowel enema and stool testing for occult

blood were not performed. The patient's physical examination was normal and no treatment was prescribed.

Two weeks prior to admission he had melena, one stool daily for two days and was placed on oral ranitidine 150 $\mathrm{mg}$ bid. The patient noted a rapid and marked improvement in his abdominal pain. Ten days later ranitidine was discontinued when esophagogastroduodenoscopy was normal. The patient's abdominal pain returned within $24 \mathrm{~h}$ and steadily increased in intensity for three days until his arrival at the emergency department. On arrival he had

Division of Gastroenterology, Ottawa Civic Hospital, Ottawa, Ontario

Correspondence and reprints: Dr Dilip G Patel, Associate Professor, Division of

Gastroenterology, Ottawa Civic Hospital, 1053 Carling Avenue, Ottawa, Ontario K1Y 4 L9.

Telephone (613) 761-4501

Received for publication November 19, 1989. Accepted February 13, 1990 generalized, severe, constant abdominal pain and clinical signs of peritonitis. He was taken to surgery when a Meckel's diverticulum lined with gastric mucosa and a perforated ileal ulcer was found (Figures 1,2).

\section{DISCUSSION}

An unusual diverticulum of the small intestine was first described by Hildanus in 1598 (1) and was considered to be due to increased intestinal pressure. This most common congenital anomaly of the gastrointestinal tract is due to failure of obliteration of the omphalomesenteric duct connecting yolk sack to intestinal tract at five to seven weeks of gestation. Johann Friedrich Meckel established the condition on a sound embryological and anatomic basis in writings between 1808 and 1820 (2). He was incorrect, however, in predicting a $25 \%$ complication rate; the actual figures are 0.03 to $0.96 \%$ per year with a life long risk of approximately $4 \%$ (3).

The clinical diagnosis of symptomatic Meckel's diverticulum can be difficult as illustrated by this case. Some physicians feel that this is a disease of childhood and are not aware of the difference in adult presentation. Symptomatic Meckel's diverticulum in adults has a male to female ratio of 1.8 to 1.0 and the risk is greatest in the 16 to 25 year age group (mean 39 , range 16 to 87 ) (4). In children, rectal bleeding and obstruction are the most common complications, while 30 to $50 \%$ of adults experience inflammation, 33 to 


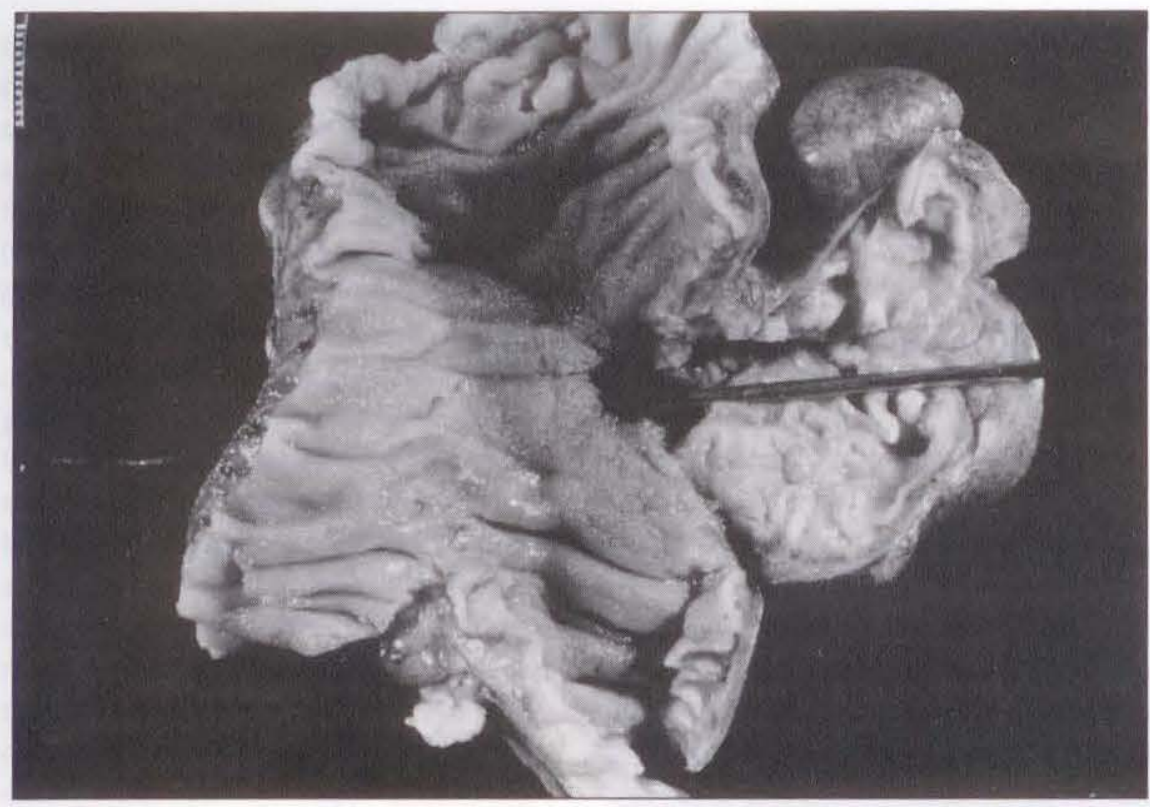

Figure 1) Gross appearance of perforated ileal ulcer

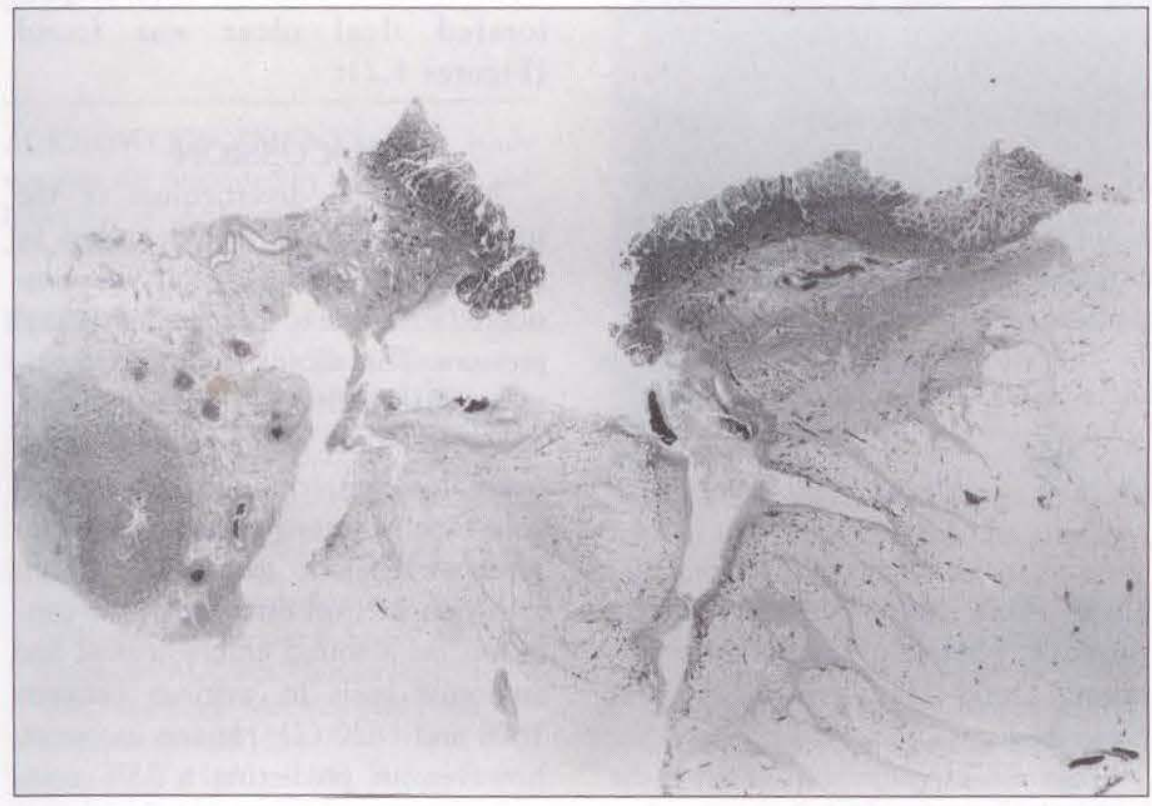

Figure 2) Microscopic appearance of perforated ileal ulcer (x 4.5)

$36 \%$ obstruction, $19 \%$ perforation and 10 to $19 \%$ bleeding.

Any young adult with significant gastrointestinal bleeding and a negative endoscopic evaluation should be investigated for a possible Meckel's diverticulum. Patients with inflammation are likely to be diagnosed as appendicitis and managed surgically at an early stage.

A computer search of the world literature to 1989 revealed only five case reports of $\mathrm{H}_{2}$ blocker therapy in Meckel's diverticulum and several noteworthy features were found (Table 1). Bleeding from a Meckel's diverticulum is rare above age 30 years (4) and the present patient was significantly older than the others treated. One-half of the patients had postprandial pain, and five of six had obvious rectal bleeding. Upper intestinal series performed in four cases were falsely negative but two small bowel enemas were positive for Meckel's diverticulum. Four Meckel's scans were reported in three patients with two positive and two negative results.
A question raised by the present case concerns the diagnostic and therapeutic value of $\mathrm{H}_{2}$ blockers in symptomatic Meckel's diverticulum. In the five cases where detail was provided, all mentioned rapid improvement in abdominal pain with institution of $\mathrm{H}_{2}$ blockade. In all three cases in which the $\mathrm{H}_{2}$ blocker was discontinued the pain returned. The data sug. gest that abdominal pain which responds to $\mathrm{H}_{2}$ blockers in the absence of evidence of upper intestinal disease should prompt an investigation for Meckel's diverticulum.

A therapeutic role for $\mathrm{H}_{2}$ blockers has been advocated by some (5-7), while others noted rebleeding and perforation during treatment $(8,9)$. The fact that $\mathrm{H}_{2}$ blockers were ineffective for reducing bleeding from duodenal ul. cers plus the fact that such bleeding resolved spontaneously in $80 \%$ of cases is important; however, it is not possible to draw any therapeutic conclusion from this small group of patients.

The present patient had gastric tissue present in his Meckel's diverticulum which has been correlated with the presence and nature of symptoms in this condition. Depending upon the thoroughness of the search, ectopic tissue is present in 25 to $72 \%$ of symp. tomatic patients $(10,11)$. In one large series only $16 \%$ of patients with ectopic tissue were asymptomatic (4). Tissue types include gastric $(60 \%)$, pancreatic $(16 \%)$ and mixed $(22 \%)(10,11) ; 92$ to $100 \%$ of Meckel's diverticula complicated by bleeding are associated with heterotopic tissue $(4,10)$. Efforts have been made to correlate the presence of gastric mucosa with the likelihood of bleeding. Parietal cells present in gastric mucosa have been demonstrated to secrete acid, and islets of Langerhans are present in pancreatic rests (10).

What avenues are available to the clinician for diagnosing Meckel's diverticulum? Upper gastrointestinal series are insensitive because the wide mouth of the diverticulum empties well and holds only a small amount of residual barium (12). A number of authors feel that enteroclysis is the most reliable method for preoperative 
TABLE 1

Clinical features of six cases of Meckel's diverticulum treated with $\mathrm{H}_{2}$ blockers

\begin{tabular}{|c|c|c|c|c|c|}
\hline Age & Sex & Symptom & Sign & Treatment & Outcome \\
\hline 27 & $M$ & Abdominal pain & Bloody stool & $\begin{array}{l}\text { Cimetidine } 300 \text { mg orally qid } \\
\text { for } 3 \text { months }\end{array}$ & $\begin{array}{l}\text { Surgery for rebleeding after } \\
\text { therapy }\end{array}$ \\
\hline 40 & M & $\begin{array}{l}\text { Peri-umbilical } \\
\text { cramps, postprandial }\end{array}$ & Melena & Ranitidine $150 \mathrm{mg}$ bid for 10 days & $\begin{array}{l}\text { Urgent surgery, perforation after } \\
\text { therapy }\end{array}$ \\
\hline 23 & M & $\begin{array}{l}\text { Sharp, infra-umbilical } \\
\text { postprandial pain }\end{array}$ & - & $\begin{array}{l}\text { Cimetidine } 300 \mathrm{mg} \text { orally every } 6 \mathrm{~h} \\
\text { for } 5 \text { days }\end{array}$ & Semi-elective surgery \\
\hline 26 & $\mathrm{~F}$ & Peri-umbilical pain & Maroon stool & Cimetidine? dose orally for 7 days & Semi-elective surgery \\
\hline 12 & M & Nonspecific pain & $\begin{array}{l}\text { Melena and fresh } \\
\text { blood rectally }\end{array}$ & $\begin{array}{l}\text { Cimetidine } 100 \mathrm{mg} \text { orally every } 6 \mathrm{~h} \\
\text { for } 3 \text { months }\end{array}$ & Perforated after therapy, surgery \\
\hline
\end{tabular}

diagnosis of Meckel's diverticulum ( 12 . 15). The barium injected under pressure highlights any constricting lesion and the regulatory effects of the gastric and pyloric areas are bypassed readily by the enteroclysis catheter.

${ }^{99}$ Technetium pertechnetate has an affinity for mucus-producing and parietal cells, and the tracer is concentrated by the ectopic gastric mucosa. Cimetidine does not interfere with uptake but reduces luminal excretion fourfold in the dog model. It is optimally delivered $24 \mathrm{~h}$ before imaging (16). Another agent used to increase the sensitivity of a Meckel's scan is penta-

ACKNOWLEDGEMENTS: The author acknowledges the excellent secretarial assistance of Mrs Cecile Humphrey.

\section{REFERENCES}

1. Fabricul H. Animadv Var Argum Med Helmst. Jan 1750. (Edit)

2. Meckel JF, Uberdie Divertikel am Darmkanal. Archdie Physiology 1809;9:421-53.

3. Soltero MJ, Bill AH. The natural history of Meckel's diverticulum and its relation to incidental removal. Am J Surg 1976;132:168-72.

4. Leijonmarck CE, Bonmon-Sondelin K, Frisell J, Raf L, Meckel's diverticulum in the adult. Br J Surg 1986;73;146-9.

5. Kirkpatrick PA. Cimetidine and Meckel's diverticulum. Ann Intern Med 1978;83:846-7.

6. Selker HP. Cimetidine and cryptic 'Dyspepsia Meckeli'. JAMA 1983; 249:1266.

7. Collins JC. Hemorrhage from a gastrin. In mice, a $65 \%$ increase in uptake is noted with pentagastrin, and some radiologists prefer the increase in scan sensitivity despite a theoretical risk of increased bleeding (17). In a large series of 954 cases, of which 700 were children, sensitivity for ectopic gastric mucosa was $85 \%$. In adults with surgically confirmed Meckel's diverticulum a sensitivity of $62.5 \%$ was reported (18). If bleeding is present, angiography warrants serious consideration (19). A prudent course would involve more than one modality being used before exclusion of the diagnosis.

Meckel's diverticulum - One case with heterotopic gastric mucosa treated with cimetidine. Arch Surg 1980;115:83-4.

8. Munchom PE, Wheeler WH, Sibert JR. Cimetidine and peptic ulceration in Meckel's diverticulum. Arch Dis Child 1980;55:321-5.

9. Manning RJ. Failure of $\mathrm{H}_{2}$ blocker therapy in a case of hemorrhage from a Meckel's diverticulum. J Clin Gastroenterol 1987:9:242.

10. Artigas V, Calbvig R, Badia F. Meckel's diverticulum. Value of ectopic tissue. Am J Surg 1986;151:631-4.

11. Diamond T, Russell CFJ. Meckel's diverticulum in the adult. $\mathrm{Br}$ J Surg 1985;72:480-2.

12. Sutton D. A Textbook of Radiology and Imaging, Vol 1, 4th edn. Chicago: Churchill \& Livingston, 1987.

13. Dixon M, Nolan DJ. The diagnosis of Meckel's diverticulum a continuing challenge. Clin Radiol 1987;38:615-9.

14. Schwartz MJ, Lewis J. Meckel's diverticulum - Pitfalls in scintigraphic detec-
In conclusion, awareness of of high risk groups, the various modes of presentation and the differences between pediatric and adult presentation are important in diagnosing symptomatic Meckel's diverticulum. Use of an $\mathrm{H}_{2}$ blocker may offer a helpful diagnostic clue but data do not support its role in treatment. A small bowel enema and a ${ }^{99}$ technetium Meckel's scan are of significant value in preoperative diagnosis. Finally, histologic information has deepened the understanding of this most frequent congenital anomaly of the intestinal tract.

tion in the adult. Am J Gastroenterol 1984;79:611-8.

15. Maglinte D, Hall R, Miller R, Chennish S. Detection of surgical lesions by small bowel enteroclysis. Am J Surg 1984:147:225-9.

16. Baum S. Pertechnetate imaging following cimetidine administration in Meckel's diverticulum of the ileum. Am J Gastroenterol 1981;76:464-5.

17. Treves S, Grand RJ, Erakles A. Pentagastrin stimulation of technetium $-99 \mathrm{~m}$ uptake by ectopic gastric mucosa in a Meckel's diverticulum. Radiology 1978;129:711-2.

18. Sfakianakis GN, Conway JJ. Detection of ectopic gastric mucosa in Meckel's diverticulum and in the observations by scintigraphy: Pathophysiology and 10 years clinical experience. J Nucl Med 1981;22:647-54.

19. Maglinte D, Jordan L, Van Hove E, et al. Chronic gastrointestinal bleeding from Meckel's diverticulum Radiological considerations. J Clin Gastroenterol 1981;3:47-52. 


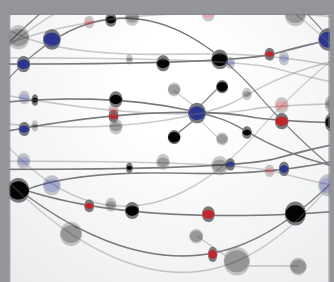

The Scientific World Journal
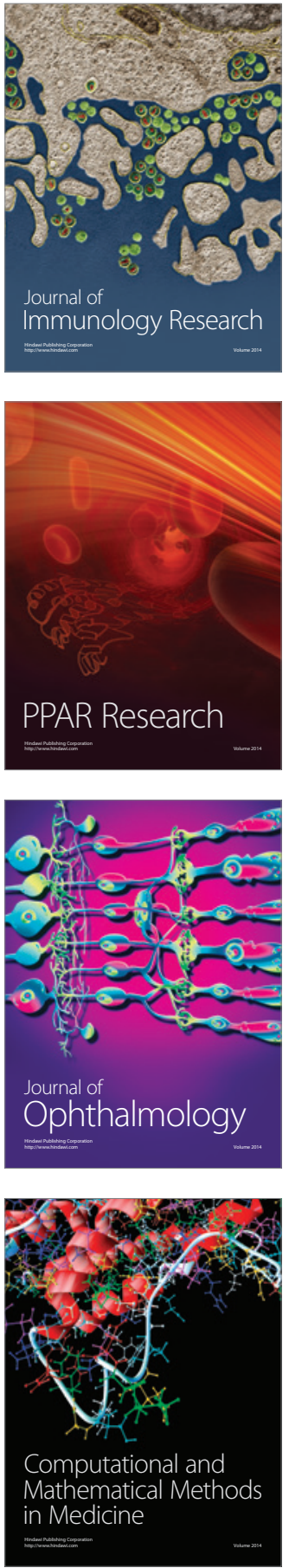

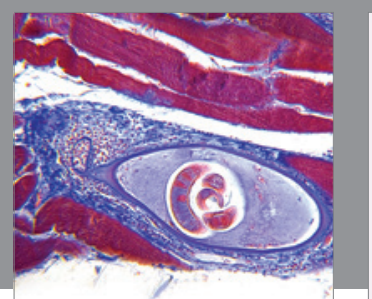

Gastroenterology Research and Practice

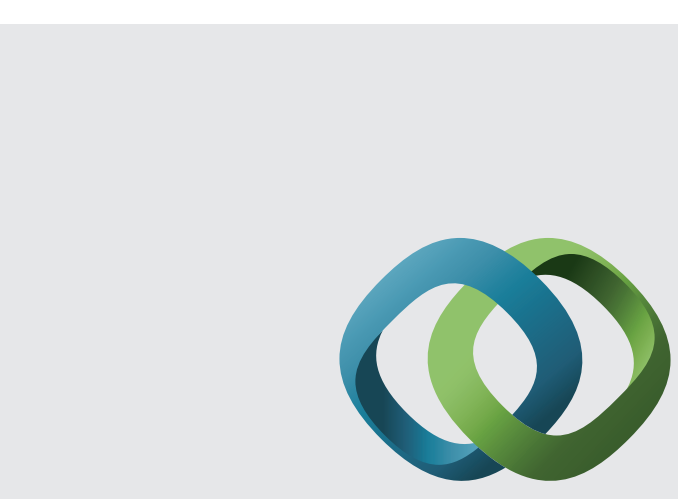

\section{Hindawi}

Submit your manuscripts at

http://www.hindawi.com
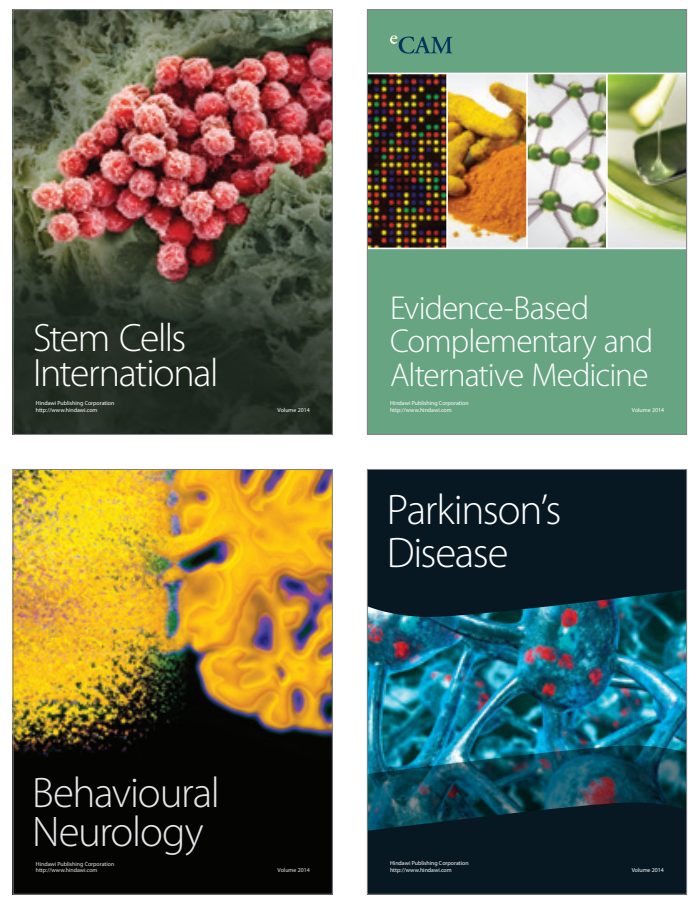
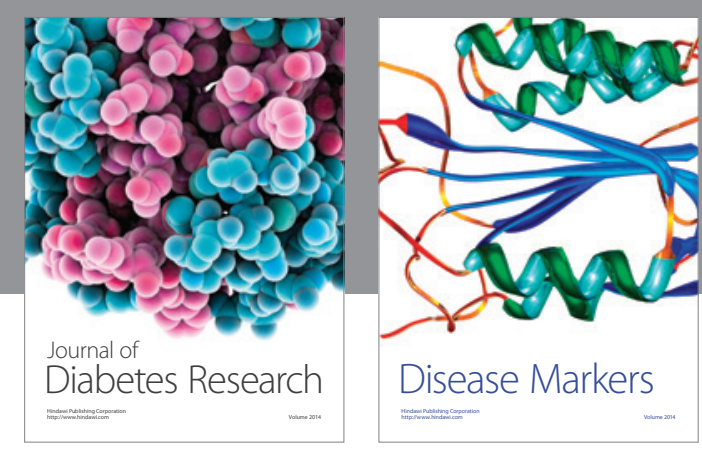

Disease Markers
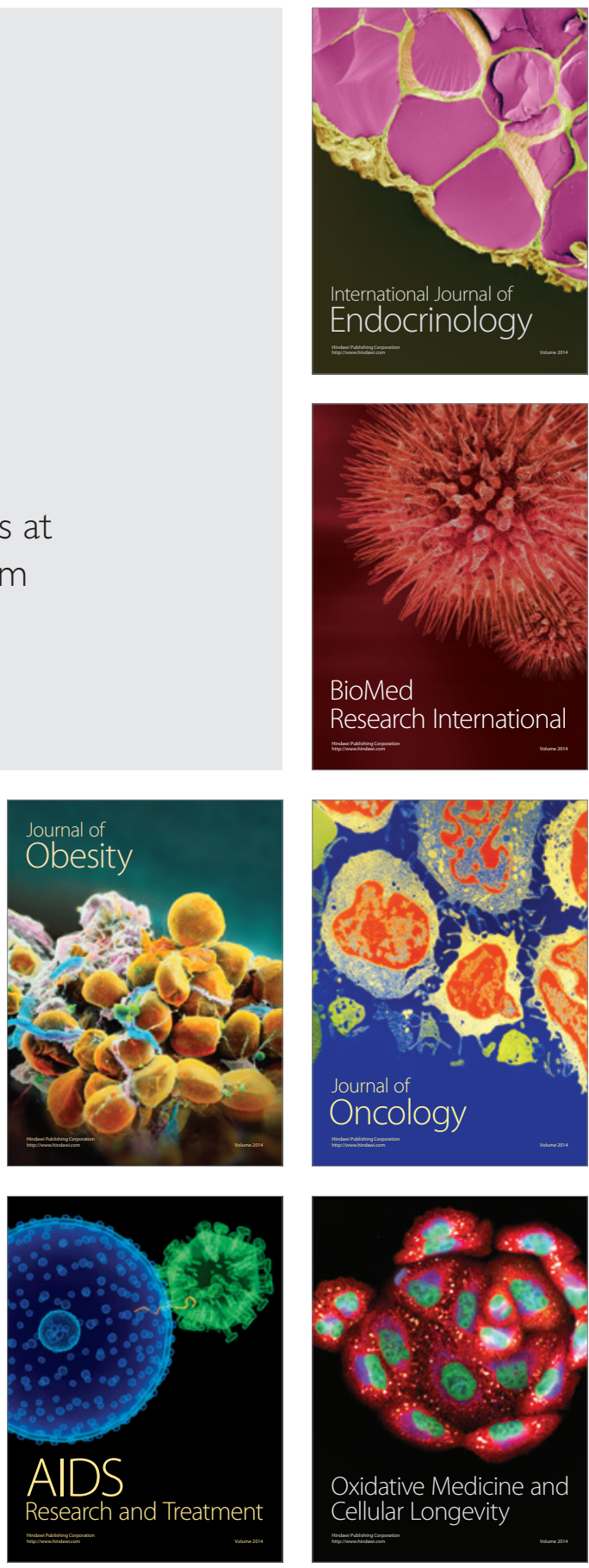